\title{
NUTRITIONAL REGULATION OF PANCREATIC AND BILIARY SECRETIONS
}

TRISTAN CORRING, CATHERINE JUSTE AND EVELYNE F. LHOSTE

Station de Physiologie de la Nutrition, INRA, 78350 Jouy-en-Josas, France

\section{CONTENTS}

INTRODUCTION . . . . . . . . . . . . . . . . . . . . . 161

PANCREATIC SECRETION AND DIETARY CHANGES . . . . 162

ADAPTATION TO THE DIET . . . . . . . . . . . . . . 162

MECHANISMS OF PANCREATIC ADAPTATION . . . . . . . . . 163

MOLECULAR REgUlation OF PANCREATIC ADAPTATION * . . . 165

Dietary changes and molecular adaptation . . . . . . . . . . . . . 165

Peptides and molecular adaptation . . . . . . . . . . . . . . . . . $\quad . \quad 167$

BILIARY SECRETION AND DIETARY FAT . . . . . . . . . 168

BILE RESPONSE TO DIETARY FAT . . . . . . . . . . . . 168

Bile salts . . . . . . . . . . . . . . . . . . . . 168

Biliary phospholipids . . . . . . . . . . . . . . . . . . . . 169

Biliary cholesterol. . . . . . . . . . . . . . . . . . 169

Relative proportions of biliary lipids: saturation of bile with cholesterol $\quad . \quad 170$

MECHANISMS OF BILE RESPONSE TO DIETARY FAT . . . . . . . . 170

BILIARY SECRETION AND DIETARY FIBRE . . . . . . . . . 171

BILE RESPONSE TO DIETARY FIBRE . . . . . . . . . . . . 171

Choledocal secretion . . . . . . . . . . . . . . . . . . . . . 171

Bile acid pool. . . . . . . . . . . . . . . . . . . 172

Bile acid metabolism . . . . . . . . . . . . . . . . . . . . . . 173

MECHANISMS OF BILE RESPONSE TO DIETARY FIBRE . . . . . 173

CONCLUSIONS . . . . . . . . . . . . . . . . . . . . . . 175

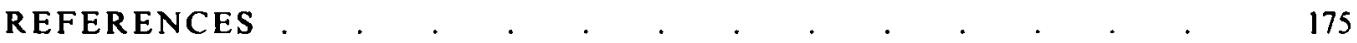

\section{INTRODUCTION}

Pancreatic exocrine secretion of a wide spectrum of enzymes together with biliary secretion which is rich in bile acids, phospholipids and cholesterol represent major digestive secretions and allow enzymic degradation of many dietary components in mammals. In animals, experimental diversion of these secretions out of the gastrointestinal tract leads to decreased digestive utilization of the diet. In humans, various pathological states lead to severe malnutrition by reduction of the gastrointestinal digestive capacity (DiMagno et al. 1973). Under physiological conditions it is now well known that the quantity of pancreatic enzymes secreted is sufficient for digestion of approximately ten times the amount of food usually ingested (Corring, 1980). However, digestive capacity may be dramatically modified 
by numerous stimuli and among them is food. Very diverse dietary factors may alter digestive secretions: carbohydrates, proteins, lipids, trace element deficiencies, enzyme inhibitors, dietary fibre, physical state of the diet, ..., etc.

Because it is not possible to summarize all these effects in the present review, we have concentrated on the adaptation of pancreatic and bile secretions to the diet. Moreover, because of its specific action on intraluminal bile acids and on their metabolism, the specific effect of fibre on bile secretion is discussed. In all cases, attention has been focused on the mechanisms involved in the relationship between digestive secretions and food.

\section{PANCREATIC SECRETION AND DIETARY CHANGES}

\section{ADAPTATION TO THE DIET}

Pavlov (1879) observed that the pancreas is able to modify its secretion in response to the composition of diet. This phenomenon has been widely confirmed since then, using more and more sophisticated techniques (Desnuelle et al. 1962; Corring, 1980). In animals proteolytic enzyme activity, either in pancreatic tissue or in pancreatic juice entering the duodenum, is modified by the protein content of the diet, while amylase and lipase (EC 3.1 .1 .3 ) activities are respectively dependent on the carbohydrate and lipid contents in the diet. These variations depend on parallel increases or decreases in enzyme biosynthesis (Reboud et al. 1966; Poort \& Poort, 1980). In humans, too few studies have been performed so far to demonstrate clearly the adaptation of pancreatic secretion to diet composition. According to Lebenthal $e t$ al. (1981) it does exist in premature infants, but Emde $e t$ al. (1985) failed to demonstrate any adaptive change in pancreatic amylase and lipase secretion in response to a $10 \mathrm{~d}$ continuous intraduodenal infusion of a high-carbohydrate, low-fat diet in adults.

During the past 20 years, studies of pancreatic adaptation to the diet have covered such enzymes as phospholipase (Prost et al. 1978) and carboxypeptidases (Berger \& Schneeman, 1986). Regarding adaptation of colipase, published results are contradictory. In rats Girard-Globa \& Simond-Cote (1977) reported adaptation of colipase to dietary lipids, whereas Vandermeers-Piret et al. (1977) did not observe any in either rats or mice. These conflicting findings may be explained by quantitative and qualitative differences in dietary protein ingestion (Saraux et al. 1982). Colipase adaptation to the amount of dietary lipids has been demonstrated in pigs fed on isonitrogenous diets (Mourot \& Corring, 1979).

The idea that there are minimal and maximal limits to secretion appears in the case of lipase activities in response to increasing amounts of dietary lipid. Sabb et al. (1986) demonstrated that lipase activity is not stimulated when dietary fat energy supply represents $196 \mathrm{~kJ}$ (47 kcal) or less of the total dietary energy intake; beyond this point, lipase activity increases and is maximally stimulated when fat represents $225-280 \mathrm{~kJ}$ (54-67 kcal) of the total dietary energy intake. In the same way, Bucko \& Kopec (1979) reported that the maximal pancreatic response to maize oil adaptation is obtained with a $180 \mathrm{~g}$ maize oil/kg-enriched diet. Similar observations were reported by others (Gidez, 1973; Saraux et al. 1982). In this connexion, pancreatic lipase activity appears to be influenced by the type of fat ingested (Deschodt-Lanckman et al. 1971; Saraux et al. 1982; Simoes Nunes, 1986). According to Sabb et al. (1986), pancreatic lipase adapts primarily to the amount of dietary fat and is affected by the type of the fat only below the level of maximal enzyme response.

Such limits in adaptation of other pancreatic enzymes have not been reported. Amylase is enhanced by increasing the ingested amount of starch (Noirot et al. 1981). Pancreatic proteolytic enzyme secretion is proportional or shows a 'purposive' adaptive response to the quantity of nitrogen intestinally infused in man (Vidon et al. 1978), or orally ingested 
in the rat (Schick et al. 1984 b). It is also sensitive to the type of protein orally ingested in pigs (P. Valette \& T. Corring, unpublished results), or intraduodenally infused in rats (Berger \& Schneeman, 1986).

It has been found by several authors that pancreatic adaptation to a dietary change is completed within 5-7 d and a new steady-state is established (for example, Corring \& Saucier, 1972; Bozkurt \& Haberich, 1985). Interestingly, long-term (6-9 months) dietary changes produce pancreatic exocrine responses similar to those reported in short-term studies in rats (Houghton et al. 1983). According to Poort \& Poort (1980), biosynthesis of pancreatic enzymes is modified $5 \mathrm{~d}$ after feeding rats with a protein-rich diet $v$. a carbohydrate-rich diet. Other authors showed that pancreatic biosynthesis in reponse to dietary changes occurred even earlier. For instance, Dagorn \& Lahaie (1981) reported that changes in synthesis rate occurs as early as $24 \mathrm{~h}$ after alteration in dietary composition, thus preceding changes in tissue levels of enzyme. In the pig, amylase activity in the pancreatic juice is augmented throughout the first $2 \mathrm{~h}$ following increased starch intake (Simoes Nunes \& Corring, 1979). In trying to explain why enzyme adaptation takes a relatively long time to stabilize after a change of diet, it is suggested that it depends on the adjustment to the new diet of other digestive processes such as gastric emptying or intestinal motility (Corring, 1977). On the first experimental day, changing the amount of substrate ingested would represent a stimulus which must be repeated (intake of several meals of the new diet) in order to get a full change in the bulk of gastrointestinal tract content. Indeed, Bozkurt \& Haberich (1985) found a close relationship between the time interval required for adaptation and the extent of change in dietary components in rats: the adaptation of proteolytic enzymes requires about 7-8 $\mathrm{d}$ when the dietary protein content varies from 100 to $570 \mathrm{~g} / \mathrm{kg}$ and only $3-4 \mathrm{~d}$ when varying from 240 to $570 \mathrm{~g} / \mathrm{kg}$. In addition, it has been emphasized that adaptation to a protein-rich diet occurs at a faster rate than adaptation to a carbohydrate-rich diet (Lahaie \& Dagorn, 1981) and lipase activity reaches its maximum even faster (Deschodt-Lanckman et al. 1971), suggesting that different mechanisms are involved in adaptation to each type of dietary nutrient.

Today, pancreatic adaptation to diet appears much more complex than was expected by the first experimenters. Each enzyme behaves differently, depending on the amount and the type of substrate ingested. The mechanisms involved are still largely unknown and we will now consider some hypotheses for explaining adaptive processes.

\section{MECHANISMS OF PANCREATIC ADAPTATION}

In an animal adapted to a specific nutrient-enriched diet, the high level of this nutrient in the digestive tract is very rapidly followed by increased corresponding enzyme levels in the pancreas, although no contact between the nutrient and the pancreas has occurred. The ingested nutrients very rapidly undergo physical and biochemical degradation, initially in the stomach. The stomach evacuates a mixture of nutrients and hydrolysis products into the duodenum. Therefore, the information sent to the pancreas may be generated by the substrate or its hydrolysis products. Several studies are described later which attempt to identify which product was responsible for pancreatic adaptation to diet and which second messenger was involved.

The increase induced by starch on amylase synthesis is comparable to that induced by its hydrolysis products, glucose (Robberecht et al. 1971) or D-glucose (Grossman et al. 1944). Nevertheless, according to Noirot et al. (1981) starch feeding is a better amylase stimulant than simple sugar feeding. Replacement of intact protein by its acid- or enzymic hydrolysis products in the diet does not lead to any increase in proteolytic enzyme levels but, on the contrary, to their decrease (Grossman et al. 1944; Howard \& Yudkin, 1963), suggesting that the intact molecule is responsible for pancreatic adaptation to a protein- 
enriched diet. However, these studies were performed in the rat, which is unusual because only specific intact proteins significantly modify pancreatic secretion (Schneeman et al. 1977; Green \& Miyasaka, 1983). Similar studies using oral ingestion of hydrolysis products have not been performed yet in other species. However, in man and in the dog pancreatic secretion is stimulated by peptides and intestinal infusion of amino acids (Meyer \& Kelly, 1976; Meyer et al. 1976) as well as by intestinal infusion of lipids and their hydrolysis products (Malagelada et al. 1976). It is now assumed that hydrolysis products act on the intestinal mucosa which secretes the so-called second messenger. This hypothesis is clearly sustained by the following findings. First, intravenous fat and amino acids do not affect pancreatic secretion in dogs (Stabile et al. 1984; Burns \& Stein, 1987), while in humans intravenous lipid does not stimulate pancreatic secretion (Edelman \& Valenzuela, 1983). Parenteral administration of glucose has been shown either to have no effect on amylase secretion in the dog (Stabile et al. 1984) or to decrease it (dog, Saito et al. 1978; humans, Dudrick et al. 1970; pig, Simoes Nunes \& Corring, 1981). Only Konturek et al. (1979) found a significant increase in pancreatic enzyme secretion during short-term intravenous administration of lipid and amino acid infusions in dogs suggesting that these molecules have to pass through the intestinal wall to provoke the pancreatic response to food ingestion. Nevertheless, such results are inconsistent with those of most authors.

It is of note that almost all the experimental findings emphasize the effect of hydrolysis products on the pancreatic secretion before their intestinal absorption, indicating an active involvement of the intestinal mucosa through the release of the second messenger. Thus, Dick \& Felber (1975) have reported that injection of duodenal extracts from rats fed on different meals into the coeliac artery of recipient rats elicits the secretion of related pancreatic enzymes. Simoes Nunes \& Corring (1980) reported very similar results in the pig and Simoes Nunes (1982) showed in addition that pancreatic adaptation to dietary carbohydrates and lipids is no longer observed after proximal small intestine bypass in the pig. In contrast and according to Simoes Nunes (personal communication) pancreatic proteolytic enzyme adaptation to dietary proteins does not depend on the proximal small intestine. Bozkurt \& Haberich (1985) reported that starch instillation into the duodenum leads to a rapid increase in amylase secretion, whereas intraduodenal amino acids and lipids somewhat delay the respective responses of proteolytic enzymes and lipase. If, as seems likely, the intestinal mucosa is involved in the adaptation of the pancreas to the diet, the mechanisms are probably different for each enzyme considered (Bozkurt \& Haberich, 1985) and would involve mainly peptides. Information concerning nervous control of the pancreatic adaptation to the diet is scarce. According to Morisset \& Dunnigan (1967) pancreatic adaptation to the diet is not affected in the vagotomized rat.

Among regulatory peptides, cholecystokinin is often considered to be the main intestinal factor for pancreatic adaptation to diet. According to Green et al. (1986), cholecystokinin is involved in the pancreatic protease adaptation to dietary protein in the rat. It is known that cholecystokinin is released in the intestine by food substances and their hydrolysis products. In the rat, intact dietary proteins, but not casein hydrolysate, are potent stimuli of cholecystokinin (Liddle et al. 1985), as are fat and carbohydrate, although to a lesser extent than casein (Douglas et al. 1988). In man, according to Hopman et al. (1985), fat and protein, but not starch, are effective stimuli for the secretion of cholecystokinin, when ingested in equal amounts. However, according to Bozkurt \& Haberich (1985), the peptide does not have any specific effect on proteolytic enzymes, but rather a general stimulatory action on every pancreatic enzyme. In the pig, Corring \& Chayvialle (1987) reported that cholecystokinin, as well as secretin, somatostatin and pancreatic polypeptide, are not involved in the respective adaptation of amylase and lipase to dietary carbohydrates and lipids. According to Wood et al. (1988), neurotensin does not control lipase adaptation to 
dietary lipids in the rat. If peptides, which are known to regulate the exocrine pancreas, do not play an essential role in the adaptation of secretion to the diet, the involvement of currently unknown peptide-like components is suggested (Dick \& Felber, 1975; Corring, 1977).

Until recently, scientists interested in the problem of how the pancreatic enzymes adapt to the diet have used classical tools such as biochemistry and physiology. However, recent developments in molecular biology are now being used to elucidate the cellular and molecular basis of pancreatic adaptive response to dietary changes.

\section{MOLECULAR REGULATION OF PANCREATIC ADAPTATION}

The mechanisms of gene expression have been widely studied during the past 20 years. Among numerous reviews, those of Puigserver et al. (1985), Scheele (1986), Goodridge (1987) and Kern et al. (1987) have emphasized current knowledge of gene expression and its regulation in the gastrointestinal tract.

Briefly, proteins are synthesized through translation of a pattern provided by mRNA nucleotide sequences. A specific gene sequence located on DNA serves as a template for transcription. The resultant primary RNA transcript is processed through splicing, capping and tailing into mature mRNA. Several factors may influence the rate of gene transcription and mRNA translation: efficiency of transcription, processing and transport of the primary transcript, stability of mature cytoplasmic mRNA and efficiency of translation. Numerous molecular biology techniques are now available to reveal these physiological phenomena (for review, see Goodridge, 1987).

\section{Dietary changes and molecular adaptation}

In studies showing pancreatic enzyme adaptation in the rat, protein biosynthesis was directly measured (1) in vivo by single labelling (Reboud et al. 1966; Dagorn \& Lahaie, 1981; Lahaie \& Dagorn, 1981), (2) in vitro by single labelling in pancreatic slices (Reboud et al. 1966), or in pancreatic lobules (Wicker et al. 1983, 1984; Schick et al. 1984a,b), (3) in vitro by double labelling of pancreatic slices (Poort \& Poort, 1980, 1981) followed by separation of radiolabelled protein products by polyacrylamide gel (Poort \& Poort, 1981) and isoelectrofocusing (Dagorn \& Lahaie, 1981). The first method leads to very rough values because they are expressed relative to total enzyme activity; therefore, secreted proteins are not included. The second method is more precise because it avoids estimation of enzyme activity, but these values express relative differences between one diet and another. Lobules are usually considered to be better models than slices because less tissue is spoilt during preparation, the pieces are smaller and, therefore, better exposed to the incubation medium, while preserving intercellular communications.

In the rat pancreas, twenty-one individual exocrine proteins have been identified by twodimensional electrophoresis: four forms of procarboxypeptidase, three forms of trypsinogen, two or three forms of amylase, two forms each of chymotrypsinogen and proelastase, one form each of lipase and RNAse (EC 3.1.27.5), and four unidentified glycoproteins (Poort \& Poort, 1981; Schick et al. 1984a). In the rat, it has been demonstrated that, following treatment ( $5 \mathrm{~d}-3$ weeks) with diets containing normal (220 $\mathrm{g} / \mathrm{kg})$-high $(820 \mathrm{~g} / \mathrm{kg})$ protein levels at the expense of carbohydrate, amylase and the majority of proteases are synthesized in direct proportion to amounts of their corresponding nutritional substrates in the diet. However, chymotrypsinogen, anionic trypsinogen, proelastase 1 and procarboxypeptidases are the most markedly modified. Trypsinogen 3, proelastase 2, RNAase and lipase are not altered (Poort \& Poort, 1980, 1981; Schick et al. $1984 b$ ). These findings indicate differential effects of diet on the biosynthesis of serine 
proteases and other proteolytic enzymes from the point of view of both extent and timing of enzyme response. Further work is needed to determine whether such effects are modulated by the quality of protein ingested. It appears that study of the regulation of gene expression at the molecular level is necessary for a better understanding of pancreatic adaptation to diet.

Quantification of specific mRNA expression would indicate whether the control of gene expression is located at the translational or pretranslational level. mRNA enzyme concentrations have been measured either by in vitro translation in a cell-free system (Giorgi et al. 1984; Wicker et al. 1984) or by hybridization of mRNA immobilized on filters to labelled cDNA-cloned probes (Giorgi et al. 1984, 1985). A good correlation was observed between values obtained by both methods; the latter tends to be widely used because it is less time-consuming and more sensitive.

In general, the concentrations of all mRNA tested in the previously described studies have been found to vary in the same manner as the intrapancreatic levels of the enzymes. However, the concentration of mRNA coding for amylase is 9-fold higher in a diet with $750 \mathrm{~g}$ carbohydrate $/ \mathrm{kg}$ than in one containing $110 \mathrm{~g}$ carbohydrate $/ \mathrm{kg}$, whereas the rate of enzyme synthesis is only increased 4-fold (Giorgi et al. 1984), suggesting that part of the mRNA may be stored in the cell for a further increase in protein biosynthesis, and that translation of amylase mRNA is a rate-limiting reaction in that case. Concerning serine proteases, elastase (EC 3.4.21.36) expression is only significantly increased by a $700 \mathrm{~g}$ protein $/ \mathrm{kg}$ diet, while chymotrypsinogen and especially trypsinogen expression are already increased after a $250 \mathrm{~g}$ protein/ $\mathrm{kg}$ diet (Giorgi et al. 1985), suggesting that the control is mostly pretranslational and showing that the expression of genes is not affected to the same extent and with the same sensitivity.

Part of these findings is supported by Wicker et al. (1984) who found a good correlation between the protein biosynthesis rate and mRNA levels of amylase and serine proteases (chymotrypsinogen, trypsinogen and proelastase) in rats given high- or low-protein diets and concluded that the control was mostly pretranslational. Moreover, studies using actinomycin $\mathbf{D}$, an inhibitor of transcription, have demonstrated that only trypsinogen 1 and proelastase $1 \mathrm{mRNA}$ half-lives are modified after feeding a protein-rich diet (Puigserver et al. 1985).

In conclusion, the control of enzyme synthesis adaptation to a protein-rich diet is probably both pretranslational (transcription or mRNA stability, or both) and translational. Furthermore, the nature and intensity of this control may vary with each enzyme.

As far as control of lipase synthesis is concerned, the first detailed studies have only been published very recently. In a preliminary study it was shown that, on a lipid-rich diet, lipase mRNA increases with pancreatic lipase content, although this increase is more modest than that of proteases after a protein rich diet (Giorgi et al. 1983). Administration of a high-lipid, low-carbohydrate diet to rats for $10 \mathrm{~d}$ results in an increase in lipase protein synthesis and mRNA contents and a decrease in amylase protein synthesis and mRNA contents (Wicker \& Puigserver, 1987; Wicker et al. 1988). Ingestion of diets containing $30-200 \mathrm{~g}$ fat $/ \mathrm{kg}$ progressively increases the synthesis of lipase, chymotrypsinogen 1, proelastase 1 , whereas no further increase is observed with 250 or $300 \mathrm{~g}$ fat $/ \mathrm{kg}$ in the diet. But procarboxypeptidases and, to a lesser extent, trypsinogen 1 are only increased after consumption of diets containing 250 or $300 \mathrm{~g}$ fat $/ \mathrm{kg}$. The enhancement of mRNA levels is proportionally less than that of biosynthesis, suggesting a major pretranslational control (via mRNA transcription, process, transport or stability) and a minor translational control. It is of interest to point out that here again there were differences among serine proteases.

It appears, therefore, that different responses can be observed in terms of biosynthesis of 
different enzymes hydrolysing the same nutrient. This can be explained partly by the (largely putative) specificity of enzymes towards a particular type of dietary protein. Studies of the variations of gene expression in response to quantitatively identical but qualitatively different protein-enriched diets are needed.

\section{Peptides and molecular adaptation}

Several peptides are thought to be intermediates between ingested nutrients and the pancreas. Comparison of the molecular effects of these peptides on pancreatic enzyme synthesis may help to determine their importance in adaptation to diets.

Stimulation with caerulein, a synthetic analogue of cholecystokinin, revealed both coordinate and anticoordinate rate changes (latency, kinetics and extent) in protein synthesis. Acute caerulein $(25 \mu \mathrm{g} / \mathrm{kg}$ per h) administered to rats decreases amylase and increases anionic trypsinogens 1 and 2, chymotrypsinogens, procarboxypeptidases and RNAse within $3 \mathrm{~h}$, while cationic trypsinogen 3, elastase 2 and lipase synthesis are not modified (Schick et al. 1984a). These findings are compatible with those observed after protein-rich diets. However, pronounced changes in individual enzyme biosynthesis are not accompanied by changes in mRNA levels, at least during the initial $6 \mathrm{~h}$ of caerulein stimulation $(0.25 \mu \mathrm{g} / \mathrm{kg}$ per $\mathrm{h})$; mRNA levels are progressively modified thereafter up to $24 \mathrm{~h}$ (Wicker et al. 1985). Consequently, it has been suggested that during the early periods of caerulein stimulation, the anticoordinate changes observed in protein synthesis occur at the level of efficiency of mRNA translation. However, additional control at a transcriptional or post-transcriptional level may well take place, particularly with continuation of caerulein administration for 12-24 h. Indeed, Renaud et al. (1986) have shown that chronic stimulation of pancreatic secretion with caerulein or cholecystokinin $(6 \mu \mathrm{g} / \mathrm{kg}$ and $120 \mathrm{U} / \mathrm{kg}$ respectively, twice daily for $7 \mathrm{~d}$ ) leads to a preferential accumulation of trypsinogen 1 and chymotrypsinogen B mRNA compared with amylase mRNA. This increase is parallel and proportional to protein synthesis, suggesting a pretranslational control. Thus, following caerulein stimulation, there appears to be at least two distinct and overlapping phases in the regulation of gene expression. The anticoordinate changes observed in protein synthesis in both phases are similar, but the initial period may be mostly regulated at the translational level, while throughout the treatment pretranslational regulation takes place and is maintained up to $7 \mathrm{~d}$. Further research is needed to determine whether changes in mRNA levels during late periods of acute treatment or after chronic treatment for several days are mediated by changes in transcription rate, mRNA turnover or both.

The previously discussed findings do not clearly demonstrate that cholecystokinin is the effector of adaptation to a protein-rich diet in the rat. However, variations in enzymic changes described in both diet adaptation and peptide treatment may come from the relatively high doses of peptide administered and the duration of treatment. Therefore, additional experiments with endogenous modifications of cholecystokinin levels (such as trypsin-inhibitor feeding) and exogenous administration of low levels of this peptide are necessary. No doubt the recently improved models for exocrine acinar cell culture will help solve this problem.

As far as adaptation to a high-carbohydrate diet is concerned, insulin may be revealed as a good hormone candidate. To date, it has been demonstrated by hybridization techniques that amylase mRNA levels increase while chymotrypsin and elastase mRNA levels decrease following insulin treatment in rats (Korc et al. 1981). These findings suggest that insulin acts at the pretranslational level (transcription or process), as does a highcarbohydrate diet, thus corroborating the hypothesis of a role for insulin in this phenomenon.

Analyses of molecular pathways for the control of transcription and translation are in 
progress. Identification of cis-acting elements (i.e. sequences in the same DNA molecule as the gene) which may influence the rate of transcription of a specific enzyme in the pancreas was initiated by the Rutter group (Stratowa \& Rutter, 1986). Their work has focused on the effect of calcium on the regulation of gene expression in a rat exocrine pancreas cell line AR-42J. They demonstrated that $\mathrm{Ca}$ is the main intracellular messenger for trypsinogen induction and for amylase, chymotrypsinogen and procarboxypeptidase inhibition, via the calmodulin route rather than the protein kinase $C$ route. They have suggested that sequences in the $5^{\prime}$ region of these genes contain putative promoter sequences which may interact with the intracellular messenger to influence the transcription rate of a specific gene.

So far, Pinsky et al. (1985) have identified the $5^{\prime}$ non-coding region of anionic trypsinogen ( 1 and 2 ) mRNA which may influence its rate of translation during caerulein stimulation. The 5 ' non-translated regions of dog and rat anionic trypsinogen $m$ RNA have a conserved sequence involving nine contiguous and identical nucleotides; this was not observed in the twenty-nine nucleotides of the $5^{\prime}$ non-translated region of cationic trypsinogen 3 . It was suggested that base pairing of this conserved sequence to the $3^{\prime}$ end of the small ribosomal unit may increase the efficiency of mRNA translation by modifying the configuration of the molecule (Kern et al. 1987).

Although these findings need refinement, it is of interest to point out that it is now possible to investigate the intracellular pathways of enzyme synthesis control.

\section{BILIARY SECRETION AND DIETARY FAT}

\section{BILE RESPONSE TO DIETARY FAT}

There has been great interest in the effect of dietary fat on biliary secretion, because the latter represents the main route of cholesterol elimination. Interpretation of experimental results, however, is often complicated by imprecise dietary information, an uncontrolled rate of feeding, or interruption of the enterohepatic circulation. Therefore, it is not surprising that great controversies still persist in this field. In the following account, an attempt will be made to draw general conclusions where the information allows, and to state the remaining problems. The influence of both the quantity and the nature of dietary triglyceride on biliary physiology will be discussed. The role of dietary cholesterol, phytosterols, or bile salts on biliary physiology will not be reviewed here because it has already been discussed (Sarles et al. 1970) in connexion with the aetiology of biliary cholesterol gallstones.

\section{Bile salts}

Most authors have reported an increased biliary output rate following a raised dietary fat intake (Dowling et al. 1971; Redinger et al. 1973). However, there are two reports of unchanged (Portman \& Mann, 1955; Boquillon \& Clément, 1979) and one report of decreased (Davis et al. 1977) bile salt secretion rate when feeding rats with increasing quantities of fat. A general conclusion, however, reconciles the results of all the previously mentioned authors, when considering the absolute rate of lipid consumption: secretion of bile salts is definitely stimulated by fat supplementation of a diet initially low in lipid or lipid-free; the secretion rate of bile salts remains unchanged when fat supplementation is superimposed on a diet whose lipid content increases from $70-100 \mathrm{~g} / \mathrm{kg}$ to $150-200 \mathrm{~g} / \mathrm{kg}$. This is confirmed by our own experiment in pigs fed with different lipid-containing semisynthetic diets (Juste et al. 1983). However, the reason why the secretion rate of bile salts does not increase further remains unclear. The bile acid precursor cholesterol would not be the rate-limiting factor since its excretion in bile continues to increase (Juste et al. 1983); nor has the secretion rate of bile salts reached a physiological limit, since considerably 
higher output rates have been observed on a standard low-lipid diet (Juste et al. 1979). A plausible explanation appears to be that there is a limitation in bile acid absorption rate when high concentrations of dietary lipids are present in the intestinal lumen (Fondacaro, 1983).

In the rat, a high-fat diet produced higher levels of glycoconjugated and secondary bile salts compared to a standard diet (Lafont et al. 1985). However, this was not observed in the pig (C. Juste, unpublished results) in which the initial level of glycoconjugated bile salts is already very high and the initial proportion of secondary bile salts somewhat higher than in the rat.

Generally speaking, the degree of saturation of dietary long-chain triglycerides does not affect the rate of biliary bile salt output (Redinger et al. 1973; Boquillon \& Clément, 1979; Juste et al. 1986; Jadidi et al. 1988). In a number of studies, however, it was shown to be considerably increased following dietary supplements of polyunsaturated fat compared with saturated or monounsaturated fat (Dowling et al. 1971; McGovern \& Quackenbush, 1973; Ramesha et al. 1980). Dietary medium-chain triglycerides are responsible for particularly low secretion of bile salts (Redinger et al. 1973; Ladas et al. 1984).

\section{Biliary phospholipids}

Very few studies have dealt with biliary phospholipid output in relation to dietary fat content. In rats fed on a $200 \mathrm{~g}$ maize oil $/ \mathrm{kg}$ diet, the phospholipid secretion rate was 1.5 times higher than that observed with a $70 \mathrm{~g}$ maize oil $/ \mathrm{kg}$ diet (Boquillon \& Clément, 1979). It has been demonstrated (Juste et al. 1983) that in pigs the phospholipid output increases moderately when bile acid output rises sharply, when there is a change from a low- to a medium-level lard diet, whereas the phospholipid output increases much more when bile acid output is in a steady-state, when changing from a medium- to a high-level lard diet. This was interpreted as a possible synergic action between phospholipid and bile acid in the course of biliary lipid adaptation to dietary fat content, resulting in the maintenance of virtually complete dietary fat absorption (Juste et al. 1983).

The secretion rate of biliary phospholipids has been shown to be either essentially unchanged whatever the degree of saturation of dietary long-chain triglycerides (Paul \& Ganguly, 1976; Juste et al. 1983) or it is stimulated by largely unsaturated triglycerides (Redinger et al. 1973; Boquillon \& Clément, 1979). It is now clear that there is marked increase in the unsaturation of biliary phospholipids as a consequence of eating unsaturated long-chain triglycerides (Paul \& Ganguly, 1976; C. Juste unpublished results).

\section{Biliary cholesterol}

Increasing dietary fat intake either stimulates (Boquillon \& Clément, 1979), or does not alter (Sarles et al. 1970; Davis et al. 1977) the biliary secretion of cholesterol in rats. It has been demonstrated in pigs that cholesterol secretion rate rises to the same extent whether lard is increased from 20 to $100 \mathrm{~g} / \mathrm{kg}$ or from 100 to $200 \mathrm{~g} / \mathrm{kg}$ in the diet (Juste et al. 1983). Biliary cholesterol output, however, is the same with 100 or $200 \mathrm{~g}$ sunflower oil $/ \mathrm{kg}$ in the diet, and in this case, much higher than following a lard diet. This, together with the previous conflicting results, suggests that the effect of increasing dietary lipid intake on biliary cholesterol largely depends on the initial level of cholesterol in bile.

The secretion rate, as well as the concentration of cholesterol in bile, is usually higher with diets rich in unsaturated than saturated fats (Boquillon \& Clément, 1979; Ramesha et al. 1980; Juste et al. 1986). However, three research groups have observed constant output of cholesterol in bile following consumption of various diets containing saturated or polyunsaturated fats (Lewis, 1958; Wilson \& Siperstein, 1959; Dam et al. 1967).

Cholesterol secretion into bile of monkeys was decreased by medium-chain triglyceride supplementation in the studies of Redinger et al. (1973). 


\section{Relative proportions of biliary lipids: saturation of bile with cholesterol}

Since dietary fat may be responsible for unbalanced variations in the secretion of all biliary lipids, one can expect the relative composition of bile and its saturation with cholesterol to be affected too. Despite the great interest shown in the relative composition of bile in relation to diet, disagreement still persists on several points. In particular, dietary fats have been either implicated or disregarded in the determination of bile saturation with cholesterol and the incidence of gallstones. The most commonly accepted view by those who consider fats are involved is an increased saturation of bile and a disposition towards gallstone formation with unsaturated dietary fat (Sturdevant et al. 1973; Juste et al. 1985). However, some authors have found the effect of unsaturated dietary lipids to be nil (Redinger et al. 1973), or even beneficial (Dam \& Christensen, 1961) as has been seen after dietary supplementation with medium-chain triglycerides (Redinger et al. 1973).

Surprisingly, increasing the lipid content of the diet (whether saturated or unsaturated) has been shown to lower slightly the cholesterol saturation index of bile by Juste $e t$ al. (1985), while an increased saturation index was reported after a fat-free diet (Dam \& Christensen, 1961).

\section{MECHANISMS OF BILE RESPONSE TO DIETARY FAT}

Fatty acid length (Malagelada et al. 1976; Isaacs et al. 1987), intraluminal fatty acid load (Malagelada et al. 1976; Hopman et al. 1987), and fatty acid saturation (Sarles et al. 1960) can all influence gall bladder function and possibly circulation time of the bile acid pool (Gardiner \& Small, 1972; Ladas et al. 1984), through differential stimulatory effects on cholecystokinin release. According to Malagelada et al. (1976), this effect may be mediated through differences in fatty acid absorption rates: the greater the surface area of gut exposed to the stimulus of fatty acid, then the larger the amounts of cholecystokinin released, and the greater the responses of the target organs. Therefore, it was demonstrated that either medium-chain triglycerides (Isaacs et al. 1987), or a diet very poor in fat (Hopman et al. 1987), or long-chain saturated triglycerides (Sarles et al. 1960) were weak stimuli of cholecystokinin release and gall bladder contraction, as compared to long-chain unsaturated triglycerides. However, it is highly unlikely that, with ingestion of diversified dietary constituents (namely proteins and amino acids which are powerful stimuli of cholecystokinin release), differences in hormone levels would persist and could induce an immediate and significant change in biliary lipid secretion rate. Indeed, according to Grundy \& Metzger (1972), acute alteration in fat content of a formula infusion did not generally influence the hourly output of biliary lipids, whereas after 2-4 weeks of various fat intakes, clear differences appeared between dietary groups.

In other long-term experiments (Redinger et al. 1973; Juste et al. 1983, 1986) bile salt secretion rate and pool size have been shown to be related to dietary fat content. Moreover, these experiments strongly suggest that an enhanced pool size is accompanied by increased bile salt synthesis. It was therefore proposed (Redinger et al. 1973) that dietary triglycerides would have primary hepatic effects. However, no significant difference in the recycling frequency of the bile salt pool was seen between various long-chain triglyceride supplements, whilst this remained unclear in the case of medium-chain triglycerides. Accordingly, alteration in the bile acid pool size would primarily account for the long-term changes in the secretion rate of biliary bile salts following consumption of various longchain triglyceride supplements (Redinger et al. 1973; Juste et al. 1986). The lack of evidence for the involvement of the recycling frequency of bile salts in the biliary response to dietary long-chain triglycerides would appear to be confirmed by the persistence of differences 
between diets whatever time of the light-dark cycle was studied (Juste et al. 1983). Indeed, if the recycling frequency were responsible for differential secretion rates, the latter would have been essentially limited to digestive periods. Accordingly, dietary fat content would affect the bulk of bile acid absorbed per unit time, without modifying the rhythm of that absorptive activity (Juste et al. 1983). Findings obtained from intestinal loops in the rat (Sklan \& Budowski, 1977; Fondacaro \& Wolcott, 1981) would support our proposition: the rate of transport of the bile acid taurocholate across the jejunal or ileal walls depends on the type and concentration of lipid added to the luminal medium. For each lipid, there seems to be a characteristic 'optimal' concentration for maximal bile acid transport above which bile acid absorption is depressed (Sklan \& Budowski, 1977). That could be responsible for the limited increase in bile salt secretion rate in the course of biliary lipid adaptation to dietary fat content (Juste et al. 1983).

Since the biliary output of phospholipids and cholesterol is determined by the biliary output of bile salts, modulation of the latter by dietary lipid can be expected to result in alteration of the biliary secretion of phospholipid and cholesterol. However, these parallel changes may be unbalanced, resulting in an alteration in the relative composition of bile and of its saturation with cholesterol. The interrelationships of bile salts, phospholipids, and cholesterol during secretion into bile are then dependent on the level and the nature of lipids in the diet (C. Juste, unpublished results). The biliary phospholipids are essentially derived from a rapidly turning-over pool synthesized in the liver (Kawamoto et al. 1980; Barnwell et al. 1983), whereas biliary cholesterol is both newly synthesized in the liver and taken up by the hepatocyte from various circulating lipoproteins (Koelz et al. 1982; Brown \& Goldstein, 1983). This intracellular lipid material could migrate to and fuse with the canalicular membrane which would be continuously damaged by bile salts and then repaired again by new intracellular lipid material (Barnwell et al. 1984). Accordingly, complete understanding of the adaptation of biliary lipid to dietary fat content should integrate: (1) the regulation of 'biliary-type' lipid supply in the hepatocyte (phospholipid synthesis and cholesterol synthesis and uptake), (2) the eventual dietary regulation of transport of this intracellular lipid to the canalicular membrane, (3) the extent of lipid material solubilization from the canalicular membrane. The latter implies knowledge of the process of dietary alteration on the relative composition of bile salts and their micellar properties (Barnwell et al. 1983), as well as the effect of dietary fat on the lipid composition and fluidity of the membranes (Christon et al. 1988). These fields are not yet fully understood.

\section{BILIARY SECRETION AND DIETARY FIBRE}

\section{BILE RESPONSE TO DIETARY FIBRE}

\section{Choledocal secretion}

The relationship between bile secretion and dietary fibre consumption has usually been studied in terms of the fractional lipid composition of bile or bile acid metabolism. Indeed, the total amount of bile and biliary components that are passing through the bile duct to the bowel have been poorly investigated. According to the few studies available, bile flow is either stimulated (Berry-Lortsch \& Sable-Amplis, 1981; Ikegami et al. 1984; Payne et al. 1989; P. Valette \& C. Juste, unpublished results), or unchanged (Ikegami et al. 1984; Lafont et al. 1985) by dietary fibre consumption. It is interesting to parallel the usual choleresis due to dietary fibre and the strikingly high bile flow in herbivores. According to Berry-Lortsch \& Sable-Amplis (1981), dietary fibre stimulates both bile acid-independent bile flow, and bile acid-dependent flow through a greater osmotic effectiveness of fibre- 
induced bile salt species. The choleretic effect of dietary fibre is not observed after a single dose of high-fibre food (Schneeman, 1979; Ikegami et al. 1984), but becomes established progressively over the first week of treatment and remains in a steady state thereafter (Payne et al. 1989; Valette et al. 1989).

The effect of dietary fibre on the biliary bile salt output is far more complex than on total bile output, and evidence is conflicting. Total bile salt secretion rate has been found to be either increased or unaffected according to the type of dietary fibre (Ikegami et al. 1984), to the basal diet used (Lafont et al. 1985), to the initial physiopathological state of the subjects (Meyer et al. 1979; Berry-Lortsch \& Sable-Amplis, 1981), and to the duration of the fibre-enriched treatment (Payne et al. 1989; Valette et al. 1989). The total bile salt concentration in bile has been observed to be either unchanged (Berry-Lortsch \& SableAmplis, 1981; Lafont et al. 1985; Valette et al. 1989), or diminished (Berry-Lortsch \& Sable-Amplis 1981; Lafont et al. 1985; Payne et al. 1989) by fibre consumption.

There are only a few studies dealing with the effect of fibre-enriched diets on cholesterol concentration in bile, and wheat bran was used in nearly all of them. Cholesterol concentration is usually unchanged (Huijbregts et al. $1980 a$; Klapdor \& Hein, 1982; Lafont et al. 1985; Payne et al. 1989) and sometimes increased (Lafont et al. 1985) after dietary fibre supplementation, provided that the bile is initially unsaturated. The concentration of cholesterol in the bile of lithiasic patients given supplements of bran, however, decreases (Watts et al. 1978). In morbidly obese women, however, a diet with a high content of mixed dietary fibres fails to decrease the biliary cholesterol secretion rate (Meyer et al. 1979).

Still less is known about the biliary flow of phospholipids; according to Lafont et al. (1985) their concentration in bile is not modified by various high fibre treatments.

A series of reports is available on the effects of dietary fibre on the relative biliary lipid composition and lithogenic index. Wheat bran has been used in most studies. It is usually accepted that, when the bile is initially supersaturated with cholesterol, feeding wheat bran (Pomare et al. 1976; Watts et al. 1978), a concentrated wheat fibre preparation (Marcus \& Heaton, 1986 a), or high-dietary-fibre diets (Thornton et al. 1983) results in an improvement in the relative composition of bile. In subjects with normal bile composition, however, wheat bran (Wicks et al. 1978; Huijbregts et al. 1980a), oat bran (Arffmann et al. 1983), and purified fibre components (pectin, cellulose or lignin) (Hillman et al. 1986) do not further reduce the lithogenic index or alter the relative biliary lipid composition. Also, Huijbregts et al. $(1980 \mathrm{~b})$ found that the relative proportions of biliary lipids in vegetarians do not differ significantly from controls consuming a diet relatively low in dietary fibre.

\section{Bile acid pool}

The total circulating bile acid pool, whether measured by the isotope-dilution technique in gallstone patients (Marcus \& Heaton, 1986a) or by the washout technique in pigs (Payne et al. 1989) appears not to be altered by dietary wheat bran supplementation. It is, however, slightly increased by a concentrated wheat-fibre preparation (Marcus \& Heaton, 1986a) and dramatically reduced in morbidly obese women with supersaturated bile, following consumption of a diet with a high level of mixed dietary fibre (Meyer et al. 1979).

Schneeman \& Gallaher (1980) found that the total amount of bile acids in the overall intestinal contents is elevated in cellulose-fed rats (compared to those receiving a fibre-free diet). However, in rats on a wheat-bran diet, the total intestinal bile acid pool is either unchanged (Brydon et al. 1980) or decreased (Sacquet et al. 1982a). In the former case (Brydon et al. 1980), wheat brain supplementation caused an increase in the small intestinal pool and an equivalent decrease in the colonic pool. In the latter study (Sacquet $e t$ al. $1982 a$ ), wheat bran had no effect on the small intestinal pool but strongly decreased that 
of the caecum and large intestine. Pectin supplementation has no effect on the total intestinal bile acid pool in rats, although a slight decrease was observed in the bile acid pool in the caecum and colon (Sacquet et al. 1982 b).

Accordingly, there is agreement about the lowering effect of dietary fibre on the bile acid pool in the hind gut, and this is much more important with bran (Brydon et al. 1980; Sacquet et al. 1982a) than with pectin (Sacquet et al. 1982b). However, the bile acid pool was either unchanged (Sheard \& Schneeman, 1980; Sacquet et al. 1982a,b), or enlarged (Brydon et al. 1980) in the small intestine, by dietary fibre supplementation.

\section{Bile acid metabolism}

Most reports on the effects of fibre on bile acid metabolism concern experiments where wheat bran was given. It has rather consistently been found to lead to a decrease in the pool size of deoxycholic acid (Frexinos, 1981; Rigaud \& Royer, 1988), and in its relative proportion in bile (Pomare et al. 1976; Wicks et al. 1978), together with a reciprocal rise in the pool of chenodeoxycholic acid (Pomare et al. 1976; Frexinos, 1981), in its percentage in bile (Wicks et al. 1978), and in its synthesis (Pomare et al. 1976; Frexinos, 1981). This, however, is not observed when the initial fibre intake is high (Wechsler et al. 1987). This is consistent with a decrease in the percentage of biliary deoxycholate, lithocholate and total secondary bile acids, and with an increase in chenodeoxycholate observed with cellulose, a major constituent of wheat bran (Hillman et al. 1986). However, lignin, another important constituent of bran, appears to have no effect on bile acid composition. This suggested that the effects of bran supplements on bile acid metabolism are likely to be due to their high cellulose content (Hillman et al. 1986). This is confirmed by the low biliary deoxycholate concentration seen in some vegetarians (Hepner, 1975) and Nigerians (Falaiye, 1978) consuming high-cellulose diets. As a result, there is a high primary: secondary bile acids ratio in strict vegetarians (Story \& Kritchevsky, 1978) or after cellulose supplementation of the diet (Hillman et al. 1986). The cholic acid pool and synthesis, however, remained unchanged in lithiasic (Pomare et al. 1976) or healthy (Wicks et al. 1978) subjects receiving bran, and this is consistent with the stability of cholic acid after feeding major purified constituents of wheat bran, namely cellulose and lignin (Hillman et al. 1986).

The effects on bile acid metabolism of a concentrated wheat bran preparation (Marcus \& Heaton, 1986a) is much less marked than those of native bran. By contrast, pectin, a highly fermentable and gel-forming dietary fibre component, exerts the opposite effects, since it lowers the percentage of primary bile acids in bile, whilst increasing the secondary bile acid deoxycholic acid (Hillman et al. 1986).

Accordingly, different fibre components may have essentially opposite effects on bile acid metabolism. This provides possible explanations for the apparently divergent results obtained from some vegetarians (Huijbregts et al. $1980 \mathrm{~b}$ ), or from populations in the South Pacific (Pomare, 1983) and Africa (Heaton et al. 1977) where large amounts of fermentable fibres are consumed.

\section{MECHANISMS OF BILE RESPONSE TO DIETARY FIBRE}

Hypotheses have been proposed to explain nearly all the findings on the relationship between bile secretion or bile acid metabolism and dietary fibre. In the following account, however, we shall consider only the mechanisms proposed to explain the well-established effects of dietary fibre on biliary physiology, and will not discuss those mechanisms dealing with still controversial effects of dietary fibre. Accordingly, the depressive effect of dietary fibre on the bile acid pool in the hind gut, the alteration of bile acid metabolism by bran 
or its components, the improvement of the lithogenic index of the initially supersaturated biles, and the usual choleretic effect of fibre supplements will be successively discussed.

It has been suggested that an increase in colonic transit time with a low-fibre diet may, in part, account for the larger pool of bile acids in the colon (Brydon et al. 1980). This was supported by Sacquet et al. (1982a) until a relationship between the decreased transit time in the hind gut and the lowered bile acid pool in this part of the gut was clearly demonstrated after consumption of wheat bran (Riottot et al. 1984). Moreover, this relationship was assumed to be independent of the fermentation that fibres produce in the hind gut, since the depressive effect of bran on both transit time and bile acid pool size in the caeco-colon does persist in the germ-free rat (Sacquet et al. 1982a; Riottot et al. 1984).

Decreased transit time in the hind gut by wheat bran (Sacquet et al. 1982a) or cellulose (Hillman et al. 1983) could also partly contribute to lower deoxycholic acid, since it would mean less time for $7 \alpha$-dehydroxylation and for absorption to occur. Marcus \& Heaton $(1986 b)$ found a clear correlation between whole-gut transit time and deoxycholic acid pool size. This was, however, contradicted by Hillman et al. (1986) according to whom there was no correlation between intestinal transit time and relative proportion or pool size of deoxycholic acid after cellulose (Hillman et al. 1986) or a wheat fibre preparation (Marcus \& Heaton 1986 b). According to Wicks et al. (1978), the 4-6 weeks delay in the deoxycholate-lowering action of bran makes it less likely that bran acts chiefly on the absorption of deoxycholate or on exposure time of its precursor to bacteria. Delayed action is easier to reconcile with reduced formation of deoxycholate through metabolic change, namely a fall in the dehydroxylating capacity of the colonic flora. Indeed, according to Hillman et al. (1986), the changes in bile acid metabolism induced by dietary fibre were most likely to result from effects on bacterial colonic metabolism. Wheat bran (Hillman et al. 1986) and its major constituent cellulose (Huijbregts et al. 1980 b), which are partly fermentable, would lower the colonic $\mathrm{pH}$, resulting in an inhibition of bacterial $7 \alpha-$ dehydroxylation with a resultant decrease in the production of deoxycholic acid. This, in turn, would lift the specific inhibition of chenodeoxycholate synthesis by deoxycholate (Pomare \& Low-Beer, 1975) or would diminish the competitive inhibition of chenodeoxycholate absorption by deoxycholate (Hofmann, 1977).

Changes in the relative composition of the bile salt pool may, in turn, influence biliary cholesterol saturation. Increasing the proportion of chenodeoxycholate in the bile acid pool is associated with desaturation of bile and gallstone dissolution (Hofmann et al. 1982), whilst deoxycholate may have the opposite effect (Low-Beer \& Nutter, 1978). Reduction in the levels of deoxycholic acid or increased chenodeoxycholic acid or both is then the most plausible explanation for the beneficial action of bran on the cholesterol saturation of bile.

Changes in the relative proportion of bile salts appearing in bile could also be partly responsible for the usually enhanced choleresis in dietary-fibre-supplemented subjects, through alteration in their osmotic effectiveness (Berry-Lortsch \& Sable-Amplis, 1981). It is, however, highly unlikely that this accounts for the entire effect of fibre on bile flow.

The response of some regulatory peptides to wheat bran consumption has been studied in connexion with concomitant biliary alteration in the pig (Langlois et al. 1987; Valette et al. 1989). The possible involvement of cholecystokinin and pancreatic polypeptide in biliary changes over the early days of bran consumption can be eliminated. The possible roles of secretin, vasoactive intestinal peptide and even somatostatin, although unlikely (Valette et al. 1989), call for further investigation. The non-implication of regulatory peptides in the response of biliary secretion to fibre consumption was previously suggested (but not demonstrated) in two reports, showing that the single administration of fibre (Ikegami et al. 1984) or fibre component (Schneeman, 1979) failed to increase bile secretion. 


\section{CONCLUSIONS}

In the present review, we have shown that dietary changes induce important modifications in pancreatic and biliary secretion physiology.

Pancreatic enzyme biosynthesis shows rapid adaptation to the amount of several ingested dietary components. These changes reach a plateau when a diet is maintained for several meals. The mechanisms involved in such a nutritional adaptation of pancreatic secretion are still unknown. Most authors have suggested that gastrointestinal peptides are the main controlling agents. However, despite a relatively great number of studies, it is not possible to reach a conclusion at present and new methodologies are needed before the picture can be clarified. Very recently, molecular regulation of pancreatic secretion has become the centre of much interest. We believe that knowledge of the molecular steps of enzyme biosynthesis will help reveal the factors involved in pancreatic adaptation to diet. One major and promising area is the description of analogies between the effects of peptides and diets in order to compare them and finally to discover the peptides responsible for adaptation to a specific diet. Simplification of the models through cell culture systems would certainly help in this area.

Concerning biliary secretion, great differences remain on the influence of dietary lipid and fibre, even though a great number of studies have been done, particularly in relation to gallstone incidence and relative bile composition. These divergences could be largely due to actual difficulties in controlling dietary intake in human subjects, to great variations in the initial composition of the basal diets administered to humans or to animals and to the initial physiopathological states of the human subjects. Although most conclusions are limited to a specific context, some general points also emerge.

An increase in dietary long-chain triglycerides usually induces an unbalanced increase in the secretion rate of bile salts, phospholipids and cholesterol in bile and, thus, alteration in the relative composition of bile and its saturation with cholesterol. However, the importance of the lipid dietary source is still debated. Also, most authors agree that dietary fibres have a choleretic effect, with a depressive effect on the bile acid pool in the hind gut, alteration of bile acid composition and improvement of the lithogenic index of initially supersaturated bile in dietary-fibre-supplemented patients.

Mechanisms underlying biliary responses to dietary lipid or fibre have been little investigated and, thus, remain poorly understood. The non-existent or weak direct effect of regulatory peptides is, however, thought significant. Alteration in the bile acid pool through modified bile acid synthesis, intestinal transit, absorption rate and bacterial metabolism is more likely to account for the long-term changes in biliary secretion in response to dietary lipids and fibres, without important involvement of regulatory peptides.

\section{REFERENCES}

Arfimann, S., Hojgaard, L., Giese, B. \& Krag, E. (1983). Effect of oat bran on lithogenic index of bile and bile acid metabolism. Digestion 28, 197-200.

Barnwell, S. G., Godfrey, P. P., Lowe, P. J. \& Coleman, R. (1983). Biliary protein output by isolated perfused rat livers. Biochemical Journal 210, 549-557.

Barnwell, S. G., Lowe, P. J. \& Coleman, R. (1984). The effects of colchicine on secretion into bile of bile salts, phospholipids, cholesterol and plasma membrane enzymes: bile salts are secreted unaccompanied by phospholipids and cholesterol. Biochemical Journal 220, 723-731.

Berger, J. \& Schneeman, B. O. (1986). Stimulation of bile-pancreatic zinc, protein and carboxypeptidase secretion in response to various proteins in the rat. Journal of Nutrition 116, 265-272.

Berry-Lortsch, E. \& Sable-Amplis, R. (1981). Qualitative and quantitative changes in biliary secretion induced by apple consumption in hamsters. Nutrition Reports International 23, 505-516.

Boquillon, M. \& Clément, J. (1979). Effect of type and amount of dietary fat on bile flow and composition in rats. Annales de Biologie Animale, Biochimie, Biophysique 19, 1725-1736. 
Bozkurt, T. \& Haberich, F. J. (1985). Physiological studies of exocrine pancreatic secretion in conscious rats. 7 th communication: short-term kinetics of adaptation of digestive enzymes to different nutritional stimuli. Zeitschrift für Gastroenterologie 23, 257-266.

Brown, M. S. \& Goldstein, J. L. (1983). Lipoprotein receptors in the liver. Control signals for plasma cholesterol traffic. Journal of Clinical Investigation 72, 743-747.

Brydon, W. G., Tadesse, K. \& Eastwood, M. A. (1980). The effect of dietary fibre on bile acid metabolism in rats. British Journal of Nutrition 43, 101-106.

Bucko, A. \& Kopec, Z. (1979). L'adaptation du pancréas à la nature des aliments, son mécanisme. (The adaptation of pancreas to the nature of food, its mechanism.) Cahiers de Nutrition et Diététique 14, 7I-76.

Burns, G. P. \& Stein, T. A. (1987). Pancreatic enzyme secretion during intravenous fat infusion. Journal of Parenteral \& Enteral Nutrition 11, 60-62.

Christon, R., Fernandez, Y., Cambon-Gros, C., Periquet, A., Deltour, P., Leger, C. \& Mitjavila, S. (1988). The effect of dietary essential fatty acid deficiency on the composition and properties of the liver microsomal membrane. Journal of Nutrition 118, 1311-1318.

Corring, T. (1977). Possible role of hydrolysis products of the dietary components in the mechanisms of the exocrine pancreatic adaptation to the diet. World Review of Nutrition and Dietetics 27, 132-144.

Corring, T. (1980). The adaptation of digestive enzymes to the diet: its physiological significance. Reproduction, Nutrition, Développement 20, 1217-1235.

Corring, T. \& Chayvialle, J. A. (1987). Diet composition and the plasma levels of some peptides regulating pancreatic secretion in the pig. Reproduction, Nutrition, Développement 27, 967-977.

Corring, T. \& Saucier, R. (1972). Sécrétion pancréatique sur porcs fistulès. Adaptation à la teneur en protéines du régime. (Pancreatic secretion in the fistulated pig. Adaptation to the diet protein content). Annales de Biologie Animale, Biochimie, Biophysique 12, 233-241.

Dagorn, J. C. \& Lahaie, R. G. (1981). Dietary regulation of pancreatic protein synthesis I. Rapid and specific modulation of enzyme synthesis by changes in dietary composition. Biochimica et Biophysica Acta 654, 111-118.

Dam, H. \& Christensen, F. (1961). Alimentary production of gallstones in hamster. Zeitschrift für Ernährungswissenschaft 10, 36-41.

Dam, H., Kruze, I., Krogh Jensen, M. \& Kallehauge, H. E. (1967). Studies on human bile. II. Influence of two different fats on the composition of human bile. Scandinavian Journal of Clinical and Laboratory Investigation 19, 367-378.

Davis, J. W., Elliott, W. H., Foelsch, J. M. \& Ruminski, P. (1977). Role of diet on composition of rat bile. Federation Proceedings 36, 1143.

Deschodt-Lanckman, M., Robberecht, P., Camus, J. \& Christophe, J. (1971). Short-term adaptation of pancreatic hydrolases to nutritional and physiological stimuli in adult rats. Biochimie 53, 789-796.

Desnuelle, P., Reboud, J. P. \& Ben Abdeljill, A. (1962). Influence of the composition of the diet on the enzyme -content of rat pancreas. In The Exocrine Pancreas Normal and Abnormal Functions, pp. 90-114 [A. V. S. Reuck and M. P. Cameron, editors]. London: Ciba Foundation.

Dick, J. \& Felber J. P. (1975). Specific hormonal regulation by food of the pancreas (amylase and trypsin) secretions. Hormone and Metabolic Research 7, 161-166.

DiMagno, E. P., Go, V. L. W. \& Summerskill, W. H. J. (1973). Relations between pancreatic enzyme outputs and malabsorption in severe pancreatic insufficiency. New England Journal of Medicine 288, 813-815.

Douglas, B. R., Woutersen, R. A., Jansen, J. B. M. J., De Jong, A. J. L. \& Lamers, C. B. H. W. (1988). The influence of different nutrients on plasma cholecystokinin levels in the rat. Experientia 44, 21-23.

Dowling, R. H., Cowley, D., White, J. \& Campell, C. B. (1971). The effect of dietary fat on bile composition in monkeys with an intact enterohepatic circulation (EHC). European Journal of Clinical Investigation 1, 369-370 Abstr.

Dudrick S. J., Wilmore, D. W., Steiger, E., Mackie, J. A. \& Fitts, W. J. (1970). Spontaneous closure of traumatic pancreato-duodenal fistulas with total intravenous nutrition. Journal of Traumatology 10, 542-543.

Edelman, K. \& Valenzuela, J. E. (1983). Effect of intravenous lipid on human pancreatic secretion. Gastroenterology 85, 1063-1066.

Emde, C., Liehr, R. M.. Gregor M., Pleul, O., Riecken, E. O. \& Menge, H. (1985). Lack of adaptive change in human pancreatic amylase and lipase secretion in response to high-carbohydrate, low-fat diet applied by a 10 day continuous intraduodenal infusion. Digestive Diseases and Sciences 30, 204-210.

Falaiye, J. M. (1978). The dietary fibre theory and bile salt pattern in Nigerians. African Journal of Medicine and Medical Sciences 7, 151-155.

Fondacaro, J. D. (1983). Influence of dietary lipids on intestinal bile acid absorption. Proceedings of the Society for Experimental Biology and Medicine 173, 118-124.

Fondacaro, J. D. \& Wolcott, R. H. (1981). Effects of dietary nutrients on intestinal taurocholic acid absorption. Proceedings of the Society for Experimental Biology and Medicine 168, 276-281.

Frexinos, J. (1981). Les fibres alimentaires en pathologie bilio-pancréatique. (Dietary fibres in bilio-pancreatic disease). Revue Française de Gastroentérologie 165, 13-18.

Gardiner, B. N. \& Small, D. M. (1972). The effects of secretin (SEC) and cholecystokinin (CCK) on secretion of bile salts (BS) and biliary lipids. Clinical Research 20, 454 Abstr. 
Gidez, L. I. (1973). Effect of dietary fat on pancreatic lipase levels in the rat. Journal of Lipid Research 14, $169-177$.

Giorgi, D., Bernard, J. P., Lapointe, R. \& Dagorn, J. C. (1984). Regulation of amylase messenger RNA concentration in rat pancreas by food content. EMBO Journal 3, 1521-1524.

Giorgi, D., Lapointe, R., Bernard, J. P. \& Dagorn, J. C. (1983). Transcriptional regulation of pancreatic enzyme adaptation to diet. Digestion 28, 30-31 Abstr.

Giorgi, D., Renaud, W., Bernard, J. P. \& Dagorn, J. C. (1985). Regulation of proteolytic enzyme activities and concentrations in rat pancreas by food content. Biochemical and Biophysical Research Communications 127, 937-942.

Girard-Globa, A. \& Simond-Cote, E. (1977). Nutritional and circadian variations in lipase activity and colipase saturation in rat pancreas. Annales de Biologie Animale, Biochimie, Biophysique 17, 539-542.

Goodridge, A. G. (1987). Dietary regulation of gene expression: enzymes involved in carbohydrate and lipid metabolism. Annual Review of Nutrition 7, 157-185.

Green, G. M., Levan V. H. \& Liddle, R. A. (1986). Plasma cholecystokinin and pancreatic growth during adaptation to the diet. American Journal of Physiology 251, G70-G74.

Green, G. M. \& Miyasaka, K. (1983). Rat pancreatic response to intestinal infusion of intact and hydrolyzed protein. American Journal of Physiology 245, G394-G398.

Grossman, M. I., Greengard, H. \& Ivy, A. C. (1944). On the mechanism of the adaptation of pancreatic enzymes to dietary composition. American Journal of Physiology 141, 3841.

Grundy, S. M. \& Metzger, A. L. (1972). A physiological method for estimation of hepatic secretion of biliary lipids in man. Gastroenterology 62, 1200-1217.

Heaton, K. W., Wicks, A. C. B. \& Yeates, J. (1977). Bile composition in relation to race and diet: studies in Rhodesian Africans and British subjects. In Bile Acid Metabolism in Health and Disease, pp 197-202 [G. Paumgartner and A. Stiehl, editors]. Lancaster: MTP Press.

Hepner, G. W. (1975). Altered bile acid metabolism in vegetarians. American Journal of Digestive Diseases 20 , 935-940.

Hillman, L. C., Peters, S. G., Fisher, C. A. \& Pomare, E. W. (1983). Dietary effects of pectin, cellulose and lignin on stool pH, transit time and weight. British Journal of Nutrition S0, 189-195.

Hillman, L. C., Peters, S. G., Fisher, C. A. \& Pomare, E. W. (1986). Effects of the fibre components pectin, cellulose, and lignin on bile salt metabolism and biliary lipid composition in man. Gut 27, 29-36.

Hofmann, A. F. (1977). The enterohepatic circulation of bile acids in man. Clinics in Gastroenterology 6, 3-24.

Hofmann, A. F., Grundy, S. M., Lachin, J. M., Lan S-P., Baum, R. A., Hanson, R. F., Hersh, T., Hightower, N. C., Marks, J. W., Mekhjian, H., Shaefer, R. A., Soloway, R. D., Thistle, J. L., Thomas, F. B. \& Tyor, M. P. (1982). Pretreatment biliary lipid composition in white patients with radiolucent gallstones in the National Cooperative Gallstone Study. Gastroenterology 83, 738-752.

Hopman, W. P. M., De Jong, A. J. L., Rosenbusch, G., Jansen, J. B. M. J. \& Lamers, C. B. H. W. (1987). Elemental diet stimulates gallbladder contraction and secretion of cholecystokinin and pancreatic polypeptide in man. Digestive Diseases and Sciences 32, 45-49.

Hopman, W. P. M., Jansen, J. B. M. J. \& Lamers C. B. H. W. (1985). Comparative study of the effects of equal amounts of fat, protein, and starch on plasma cholecystokinin in man. Scandinavian Journal of Gastroenterology 20, 843-847.

Houghton, M. R., Morgan, R. G. H. \& Gracey, M. (1983). Effects of long-term dietary modifications on pancreatic enzyme activity. Journal of Pediatric Gastroenterology and Nutrition 2, 548-554.

Howard, F. \& Yudkin, S. (1963). Effects of dietary change upon the amylase and trypsin activities of the rat pancreas. British Journal of Nutrition 17, 281-295.

Huijbregts, A. W. M., Van Berge-Henegouwen, G. P., Hectors, M. P. C., Van Schaik, A. \& Van Der Werf, S. D. J. $(1980 a)$. Effects of a standardized wheat bran preparation on biliary lipid composition and bile acid metabolism in young healthy males. European Journal of Clinical Investigation 10, 451-458.

Huijbregts, A. W. M., Van Schaik, A., Van Berge-Henegouwen, G. P. \& Van Der Werf, S. D. J. (1980 b). Serum lipids, biliary lipid composition, and bile acid metabolism in vegetarians as compared to normal controls. European Journal of Clinical Investigation 10, 443-449.

Ikegami, S., Harada, H., Tsuchihashi, N., Nagayama, S., Nishide, E. \& Innami, S. (1984). Effect of indigestible polysaccharides on pancreatic exocrine secretion and biliary output. Journal of Nutritional Science and Vitaminology 30, 515-523.

Isaacs, P. E. T., Ladas, S., Forgacs, I. C., Dowling, R. H., Ellam, S. V., Adrian, T. E. \& Bloom, S. R. (1987). Comparison of effects of ingested medium- and long-chain triglyceride on gallbladder volume and release of cholecystokinin and other gut peptides. Digestive Diseases and Sciences 32, 481-486.

Jadidi, N., Sambrook, I. E., Owen, R. W. \& Gurr, M. I. (1988). Effect of dietary saturated and polyunsaturated fats on the composition of bile in pigs. Proceedings of the Nutrition Society 47, 99A.

Juste, C., Corring, T. \& Breant, $\mathrm{Ph}$. (1979). Excrétion biliaire chez le porc: niveau et réponse au repas (Biliary secretion in the pig: rate of output and response to feeding). Annales de Biologie Animale, Biochimie, Biophysique 19, 119-124.

Juste, C., Corring, T. \& Demarne, Y. (1985). Effet du régime lipidique sur la saturation de la bile en cholestérol chez le porc. (Effect of the lipid diet on bile saturation with cholesterol in pig). Reproduction, Nutrition, Développement 25, 815 Abstr. 
Juste, C., Demarne, Y. \& Corring, T. (1983). Response of bile flow, biliary lipids and bile acid pool in the pig to quantitative variations in dietary fat. Journal of Nutrition 113, 1691-1701.

Juste, C.. Demarne, Y. \& Corring, T. (1986). Effet du niveau et de la qualité de l'ingéré lipidique sur la sécrétion biliaire du porc en croissance. (Effect of level and source of dietary lipid on the biliary secretion in the growing pig.) Reproduction, Nutrition, Développement 26, 1191 Abstr.

Kawamoto, T., Okano, G. \& Akino, T. (1980). Biosynthesis and turnover of individual molecular species of phosphatidylcholine in liver and bile. Biochimica et Biophysica Acta 619, 20-34.

Kern, H. F., Rausch, U. \& Scheele, G. A. (1987). Regulation of gene expression in pancreatic adaptation to nutritional substrates or hormones. Gut 28, Suppl., 89-94.

Klapdor, R. \& Hein, C. H. (1982). Addition of fiber (wheat bran, bassorin) to the standard food does not influence biliary lipid composition in piglets. Research in Experimental Medicine 180, 2I-24.

Koelz, H. R., Sherrill, B. C., Turley, S. D. \& Dietschy, J. M. (1982). Correlation of low and high density lipoprotein binding in vivo with rates of lipoprotein degradation in the rat. Journal of Biological Chemistry 257, 8061-8072.

Konturek, S. J., Tasler J., Cieszkowski, M., Jaworek, J. \& Konturek, J. (1979). Intravenous amino acids and fat stimulate pancreatic secretion. American Journal of Physiology 236, E678-E684.

Korc, M., Owerbach, D., Quinto, C. \& Rutter, W. J. (1981). Pancreatic islet-acinar cell interaction: amylase messenger RNA levels are determined by insulin. Science 213, 351-353.

Ladas, S. D., Isaacs, P. E. T., Murphy, G. M. \& Sladen, G. E. (1984). Comparison of the effects of medium and long chain triglyceride containing liquid meals on gallbladder and small intestinal function in normal man. Gut 25, 405-411.

Lafont, H., Lairon, D., Vigne, J. L., Chanussot, F., Chabert, C., Portugal, H., Pauli, A. M., Crotte, C. \& Hauton, J. C. (1985). Effect of wheat bran, pectin and cellulose on the secretion of bile lipids in rats. Journal of Nutrition $115,849-855$.

Lahaie, R. G. \& Dagorn, J. C. (198I). Dietary regulation of pancreatic protein synthesis II. Kinetics of adaptation of protein synthesis and its effect on enzyme content. Biochimica et Biophysica Acta 654, 119-123.

Langlois, A., Corring. T. \& Fevrier, C. (1987). Effects of wheat bran on exocrine pancreas secretion in the pig. Reproduction, Nutrition, Développement 27, 929-939.

Lebenthal, E., Choi, T. S. \& Lee, P. C. (1981). The development of pancreatic function in premature infants after milk-based and soy-based formulas. Pediatric Research 15, 1240-1244.

Lewis, B. (1958). Effect of certain dietary oils on bile acid secretion and serum cholesterol. Lancet i, $1090-1092$.

Liddle, R. A., Green, G. M., Conrad, C. K. \& Williams, J. A. (1985). CCK response to food is species specific: fat and amino acids do not stimulate CCK release in the rat. Gastroenterology 88, 1476 Abst.

Low-Beer, T. S. \& Nutter, S. (1978). Colonic bacterial activity, biliary cholesterol saturation and pathogenesis of gallstones. Lancet ii, $1063-1064$.

McGovern, R. F. \& Quackenbush, F. W. (1973). Influence of dietary fat on bile acid secretion of rats after portal injections of ${ }^{3} \mathrm{H}$-cholesterol and $\left[4-{ }^{14} \mathrm{C}\right]$ cholesteryl esters. Lipids $8,473-478$.

Malagelada, J. R., DiMagno, E. P., Summerskill, W. H. J. \& Go, V. L. W. (1976). Regulation of pancreatic and gallbladder functions by intraluminal fatty acids and bile acids in man. Journal of Clinical Investigation 58 , 493-499.

Marcus, S. N. \& Heaton, K. W. (1986a). Effects of a new, concentrated wheat fibre preparation on intestinal transit, deoxycholic acid metabolism and the composition of bile. Gut 27, 893-900.

Marcus, S. N. \& Heaton, K. W. (1986b). Intestinal transit rate, deoxycholic acid and the cholesterol saturation of bile . three interrelated factors. Gut 27, 550-558.

Meyer, J. H. \& Kelly, G. A. (1976). Canine pancreatic responses to intestinally perfused proteins and protein digests. American Journal of Physiology 231, 682-691.

Meyer, J. H., Kelly, G. A. \& Jones, R. S. (1976). Canine pancreatic response to intestinally perfused oligopeptides. American Journal of Physiology 231, 678-681.

Meyer, P. D., DenBesten, L. \& Mason, E. E. (1979). The effects of a high-fiber diet on bile acid pool size, bile acid kinetics, and biliary lipid secretory rates in the morbidly obese. Surgery 85, 311-316.

Morisset, J. \& Dunnigan, J. (1967). Exocrine pancreas adaptation to diet in vagotomized rats. Revue Canadienne de Biologie 26, 11-16.

Mourot, J. \& Corring, T. (1979). Adaptation of the lipase-colipase system to dietary lipid content in pig pancreatic tissue. Annales de Biologie Animale, Biochimie, Biophysique 19, 119-124.

Noirot, S., Ouagued, M. \& Girard-Globa, A. (1981). Comparative effects of some carbohydrates on serum sugars, triglycerides aind digestive hydrolases. Reproduction, Nutrition, Développement 21, 727-735.

Paul, R. \& Ganguly, J. (1976). Effect of unsaturated lipids on the bile flow and biliary excretion of cholesterol and bile salts in rats. Chemistry and Physics of Lipids 17, 315-323.

Pavlov, I. P. (1879). The Work of Digestive Glands, Translated by W. H. Thompson (1910). London: Griffin and Co.

Payne, D., Juste, C., Corring, T. \& Fevrier, C. (1989). Effects of wheat bran on bile secretion in the pig. Nutrition Reports International (In the Press).

Pinsky, S. D., Laforge, K. S. \& Scheele, G. (1985). Differential regulation of trypsinogen mRNA translation : fulllength mRNA sequences encoding two oppositely charged trypsinogen isoenzymes in the dog pancreas. Molecular and Cellular Biology 5, 2669-2676. 
Pomare, E. W. (1983). Fibre and bile acid metabolism. In Fibre in Human and Animal Nutrition, pp. 179-182 [G. Wallace and L. Bell, editors]. Wellington: Royal Society of New Zealand.

Pomare, E. W., Heaton, K. W., Low-Beer, T. S. \& Espiner, H. J. (1976). The effect of wheat bran upon bile salt metabolism and upon the lipid composition of bile in gallstone patients. American Journal of Digestive Diseases 21, 521-526.

Pomare, E. W. \& Low-Beer, T.S. (1975). The selective inhibition of chenodeoxycholate synthesis by cholate metabolites in man. Clinical Science and Molecular Medicine 48, 315-321.

Poort, S. R. \& Poort, C. (1980). Effect of diet composition on the protein synthetic pattern of the rat pancreas after a feeding period of five days. Biochimica et Biophysica Acta 606, 138-147.

Poort, S. R. \& Poort, C. (1981). Effect of feeding diets of different composition on the protein synthetic pattern of the rat pancreas. Journal of Nutrition 111, 1475-1479.

Portman, O. W. \& Mann, G. V. (1955). The disposition of taurine- $\mathrm{S}^{35}$ and taurocholate- $\mathrm{S}^{35}$ in the rat: dietary influences. Journal of Biological Chemistry 213, 733-743.

Prost, J., Gillet, M. \& Belleville, J. (1978). Effets de régimes hyperlipidiques et isoprotéiques sur les activités de la lipase, de la phospholipase A2, de la cholestérolestérase, de la trypsine et de l'amylase du suc pancréatique et du pancréas de rat. (Effects of isoproteic and lipid rich diets on lipase, phospholipase A2, cholesterolesterase, trypsin and amylase activities in rat pancreatic juice and pancreas.) Journal de Physiologie 74, 743-754.

Puigserver, A., Wicker, C. \& Gaucher, C. (1985). Aspects moléculaires de l'adaptation des enzymes pancréatiques et intestinales au régime alimentaire (Molecular aspects of dietary adaptation of pancreatic and intestinal hydrolases). Reproduction, Nutrition, Développement 25, 787-802.

Ramesha, C. S., Paul, R. \& Ganguly, J. (1980). Effect of dietary unsaturated oils on the biosynthesis of cholesterol, and on biliary and fecal excretion of cholesterol and bile acids in rats. Journal of Nutrition 110, 2149-2158.

Reboud, J. P., Marchis-Mouren, G., Pasero, L., Cozzone, P. \& Desnuelle, P. (1966). Adaptation de la vitesse de biosynthèse de l'amylase pancréatique et du chymotrypsinogène à des régimes riches en amidon ou en protéines. (Biosynthesis rate adaptation of pancreatic amylase and chymotrypsinogen to starch-rich or proteinrich diets.) Biochimica et Biophysica Acta 117, 351-367.

Redinger, R. N., Hermann, A. H. \& Small, D. M. (1973). Primate biliary physiology. X. Effects of diet and fasting on biliary lipid secretion and relative composition and bile salt metabolism in the rhesus monkey. Gastroenterology 64, 610-621.

Renaud, W., Giorgi, D., Iovanna, J. \& Dagorn, J. C. (1986). Regulation of concentrations of mRNA for amylase, trypsinogen I and chymotrypsinogen B in rat pancreas by secretagogues. Biochemical Journal 235, 305-308.

Rigaud, D. \& Royer, I. (1988). Les fibres alimentaires: réalités et fictions (Dietary fibres: reality and fiction). Gastroentérologie Clinique et Biologique 12, 133-148.

Riottot, M., Sacquet, E. \& Leprince, C. (1984). Effect of wheat bran upon gastro-intestinal transit in germ-free and conventional rats. Digestion 29, 37-41.

Robberecht, P., Deschodt-Lanckman, M., Camus, J. \& Christophe, J. (1971). Induction diététique des hydrolases pancréatiques chez le rat sevré (Dietary induction of pancreatic hydrolases in the weaned rat). Archives Internationales de Physiologie et de Biochimie 79, 206-207.

Sabb, J. E., Godfrey, P. M. \& Brannon, P. M. (1986). Adaptive response of rat pancreatic lipase to dietary fat: effects of amount and type of fat. Journal of Nutrition 116, 892-899.

Sacquet, E., Leprince, C. \& Riottot, M. (1982a). Dietary fiber and cholesterol and bile acid metabolisms in axenic (germfree) and holoxenic (conventional) rats I. Effect of wheat bran. Reproduction, Nutrition, Développement 22, 291-305.

Sacquet, E., Leprince, C. \& Riottot, M. (1982b). Dietary fiber and cholesterol and bile acid metabolisms in axenic (germfree) and holoxenic (conventional) rats. II. Effect of pectin. Reproduction, Nutrition, Développement 22, 575-581.

Saito, Y., Tokutake, K., Matsuno, S., Noto, N., Honda, T. \& Sato, T. (1978). Effects of hypertonic glucose and amino acid infusions on pancreatic exocrine function. Tohoku Journal of Experimental Medicine 124, 99-115.

Saraux, B., Girard-Globa, A., Ouagued, M. \& Vacher, D. (1982). Response of the exocrine pancreas to quantitative and qualitative variations in dietary lipids. American Journal of Physiology 243, G10-G15.

Sarles, H., Badetti, J. \& Greusard, C. (1960). Etude de l'action des corps gras sur la contraction vésiculaire. I. Comparaison de l'action des dérivés des divers corps gras. (Study of the effects of fat on the gallbladder contraction. I. Comparison of the effects of various fat byproducts.) Nutritio et Dieta 2, 219-222.

Sarles, H., Hauton, J., Planche, N. E., Lafont, H. \& Gerolami, A. (1970). Diet, cholesterol gallstones, and composition of the bile. American Journal of Digestive Diseases 15, 251-260.

Scheele, G. (1986). Regulation of gene expression in the exocrine pancreas. In The Exocrine Pancreas: Biology, Pathobiology, and Diseases, pp. 55-67 [V. L. W. Go, J. D. Gardner, F. P. Brooks, E. Lebenthal, E. P. DiMagno and G. A. Scheele, editors]. New York: Raven Press.

Schick, J., Kern, H. \& Scheele, G. (1984a). Hormonal stimulation in the exocrine pancreas results in coordinate and anticoordinate regulation of protein synthesis. Journal of Cell Biology 99, 1569-1574.

Schick, J., Verspohl, R., Kern, H. \& Scheele, G. (1984b). Two distinct adaptive responses in the synthesis of exocrine pancreatic enzymes to inverse changes in protein and carbohydrate in the diet. American Journal of Physiology 247, G611-G616.

Schneeman, B. O. (1979). Acute pancreatic and biliary response to protein, cellulose, and pectin. Nutrition Reports International 20, 45-48. 
Schneeman, B. O., Chang, I., Smith, L. \& Lyman, R. L. (1977). Effect of dietary aminoacids, casein and soybean trypsin inhibitor on pancreatic protein secretion in rats. Journal of Nutrition 107, 281-288.

Schneeman, B. O. \& Gallaher, D. (1980). Changes in small intestinal digestive enzyme activity and bile acids with dietary cellulose in rats. Journal of Nutrition 110, $584-590$.

Sheard, N. F. \& Schneeman, B. O. (1980). Wheat bran's effect on digestive enzyme activity and bile acid levels in rats. Journal of Food Science 45, 1645-1648.

Simoes Nunes, C. (1982). Lack of pancreatic enzyme adaptation to diet carbohydrates and lipids after proximal small intestine bypass in the pig. Digestion 25, 108 Abstr.

Simoes Nunes, C. (1986). Adaptation of pancreatic lipase to the amount and nature of dietary lipids in the growing pig. Reproduction, Nutrition, Développement 26, 1273-1280.

Simoes Nunes, C. \& Corring, T. (1979). Pancreatic exocrine secretion in the pig following test meals of different composition and intraduodenal loads of glucose and maltose. Hormone and Metabolic Research 11, $346-351$.

Simoes Nunes, C. \& Corring, T. (1980). Rôle de la muqueuse duodénale dans l'adaptation de l'a-amylase pancréatique au régime alimentaire chez le porc. (Role of the duodenal mucosa in adaptation of pancreatic $\alpha$ amylase to diet in the pig). Reproduction, Nutrition, Développement 20, 1237-1245.

Simoes Nunes, C. \& Corring, T. (1981). Effets sur la sécrétion pancréatique exocrine du porc de l'administration intraveineuse prolongée de glucose : application à l'étude des mécanismes de l'adaptation au régime alimentaire. (Effects of prolonged intravenous glucose perfusion on pig pancreatic exocrine secretion: application to study of diet adaptation mechanisms.) Reproduction, Nutrition, Développement 21, 705-714.

Sklan, D. \& Budowski, P. (1977). The effect of lipids on taurocholate absorption from intestinal loops in the rat. Lipids 12, 193-197.

Stabile, B. E., Borzatta, M., Stubbs, R. S. \& Debas, H. T. (1984). Intravenous mixed aminoacids and fats do not stimulate exocrine pancreatic secretion. American Journal of Physiology 246, G274-G280.

Story, J. A. \& Kritchevsky, D. (1978). Bile acid metabolism and fiber. American Journal of Clinical Nutrition 31, S199-S202.

Stratowa, C. \& Rutter, W. J. (1986). Selective regulation of trypsin gene expression by calcium and by glucose starvation in a rat exocrine pancreas cell line. Proceedings of the National Academy of Sciences 83, $4292-4296$.

Sturdevant, R. A. L., Pearce, M. L. \& Dayton, S. (1973). Increased prevalence of cholelithiasis in men ingesting a serum cholesterol lowering diet. New England Journal of Medicine 288, 24-27.

Thornton, J. R., Emmett, P. M. \& Heaton, K. W. (1983). Diet and gallstones: effects of refined and unrefined carbohydrate diets on bile cholesterol saturation and bile acid metabolism. Gut 24, 2-6.

Valette, P., Corring, T., Juste, C. \& Levenez, F. (1989). Short-term effects of wheat bran incorporation into the diet on bile secretion in the pig. Nutrition Reports International (In the Press).

Vandermeers-Piret, M. C., Vandermeers, A., Wijns, W., Rathe, J. \& Christophe, J. (1977). Lack of adaptation of pancreatic colipase in rats and mice. American Journal of Physiology 232, E131-EI35.

Vidon, N., Hecketsweiler, P., Butel, J. \& Bernier, J. J. (1978). Effect of continuous jejunal perfusion of elemental and complex nutritional solutions on pancreatic enzyme secretion in human subjects. Gut 19, $194-198$.

Watts, J. McK., Jablonski, P. \& Toouli, J. (1978). The effect of added bran to the diet on the saturation of bile in people without gallstones. American Journal of Surgery 135, 321-324.

Wechsler, J. G., Wenzel, H., Swobodnik, W. \& Ditschuneit, H. (1987). Influence of increased fibre intake on biliary lipids. Scandinavian Journal of Gastroenterology 22, Suppl. 129, 185-191.

Wicker, C. \& Puigserver, A. (1987). Effects of inverse changes in dietary lipid and carbohydrate on the synthesis of some pancreatic secretory proteins. European Journal of Biochemistry 162, 25-30.

Wicker, C., Puigserver, A., Rausch, U., Scheele, G. \& Kern, H. (1985). Multiple-level caerulein control of the gene expression of secretory proteins in the rat pancreas. European Journal of Biochemistry 151, 461-466.

Wicker, C., Puigserver, A. \& Scheele, G. (1984). Dietary regulation of levels of active mRNA coding for amylase and serine protease zymogens in the rat pancreas. European Journal of Biochemistry 139, 381-387.

Wicker, C., Scheele, G. \& Puigserver, A. (1983). Adaptation au régime alimentaire du niveau des ARNm codant pour l'amylase et les protéases à sérine pancréatiques chez le rat. (Dietary adaptation of levels of mRNA coding for pancreatic amylase and serine proteases in the rat.) Comptes Rendus des Séances de $r$ Académie des Sciences 297, 281-284.

Wicker, C., Scheele, G. A. \& Puigserver, A. (1988). Pancreatic adaptation to dietary lipids is mediated by changes in lipase mRNA. Biochimie 70, 1277-1283.

Wicks, A. C. B., Yeates, J. \& Heaton, K. W. (1978). Bran and bile: time-course of changes in normal young men given a standard dose. Scandinavian Journal of Gastroenterology 13, 289-292.

Wilson, J. D. \& Siperstein, M. D. (1959). Effect of saturated and unsaturated fats on hepatic synthesis and biliary excretion of cholesterol by the rat. American Journal of Physiologv 196, 599-602.

Wood, J. G., Hoang, H. D., Bussjaeger, L. J. \& Solomon, T. E. (1988). Effect of neurotensin on pancreatic and gastric secretion and growth in rats. Pancreas 3, 332-339. 